\title{
Technological Characterization and Industrial Application of Tunisian Clays from Makthar Area (Central Tunisia) in the Ceramic Industry
}

\author{
Imed Ben Salah"1*, Moufida Ben M'Barek Jemai' ${ }^{1}$, Ali Sdiri², Najet Shimi Slim³, \\ Mabrouk Boughdiri1 \\ ${ }^{1}$ Department of Geology, University of Sciences of Bizerte, Bizerte, Tunisia \\ ${ }^{2}$ National Engineering School of Sfax, Sfax, Tunisia \\ ${ }^{3}$ Department of Geology, University of Sciences of Tunis, Tunis, Tunisia \\ Email: *imed_bensalah@yahoo.fr
}

Received 3 June 2014; accepted 25 July 2016; published 28 July 2016

Copyright (C) 2016 by authors and Scientific Research Publishing Inc.

This work is licensed under the Creative Commons Attribution International License (CC BY). http://creativecommons.org/licenses/by/4.0/

c) (i) Open Access

\section{Abstract}

This study focused on the geochemical, mineralogical and technological characterization of clays in Makthar area (Central of Tunisia) of Cretaceous-Paleogene. Its aims are to identify and promote use in the field of ceramics industry. The result of the mineralogical analysis of clays showed a dominance of illite with a percentage higher than $65 \%$, of kaolinite and smectite with percentages of $15 \%$. Geochemical analysis of the major elements of clay showed a $\mathrm{SiO}_{2}$ content exceeding $\mathbf{2 9 \%}$ and a percentage of $\mathrm{Al}_{2} \mathrm{O}_{3}$ higher than $7.5 \%$. The $\mathrm{Fe}_{2} \mathrm{O}_{3}$ percentage was ranging from $3 \%$ to $8 \%$. The percentage of $\mathrm{CaO}$ was between $22.5 \%$ and $28 \%$ while that of $\mathrm{K}_{2} \mathrm{O}$ is $4 \%$. The percentages of $\mathrm{SO}_{4}, \mathrm{MgO}$ and $\mathrm{NaO}_{2}$ were in very small fractions. Granulometric and microgranulometric analysis showed that the clay fraction $(<2 \mu \mathrm{m})$ varies from $30 \%$ to $37 \%$. The plasticity index showed the plasticity character of clays which presented a specific surface area ranging from $112 \mathrm{~m}^{2} / \mathrm{g}$ to 178 $\mathrm{m}^{2} / \mathrm{g}$ reflecting illite dominance. Drying behavior indicated that clay mixture had a drying shrinkage less than $7 \%$, while the firing shrinkage didn't exceed $2 \%$ giving the possibility of clay using in the ceramics field.

\section{Keywords}

Clay Mineral, Mineralogy, Chemical and Physical Properties, Ceramic, Industry

\footnotetext{
${ }^{*}$ Corresponding author.
} 


\section{Introduction}

The study area is located in the Tunisian Atlas (Figure 1) marked by a series of grabens in relay NW-SE direction with E-W slip fault extending from the graben of Siliana to Kef [1] [2]. These grabens were considered quaternary age [3] [4] and for other author contemporary Miocene age [5]. These authors considered that accidents EW and NE-SW are the driving mechanism of apparent discrepancy between the different facies elements as defined in the accident affecting Elles syncline.

The selected sections, located in the Northwest region Makthar, have identified three clay units from Cretaceous-Paleogene age often encountered in Tunisia:

- Unit 1 (A Mkt): This is a greenish clay sequence alternating with gray marl fossilized from Santonian-Lower Campanian age.

- Unit 2 (H Mkt): This is a sequence of clay, interspersing with centimeter levels of limestone in its middle part from upper Maastrichtian-Paleocene age.

- Unit 3 (S Mkt): This is a clay series having a thickness of $130 \mathrm{~m}$ containing a few levels of calcite from middle to upper Eocene age.

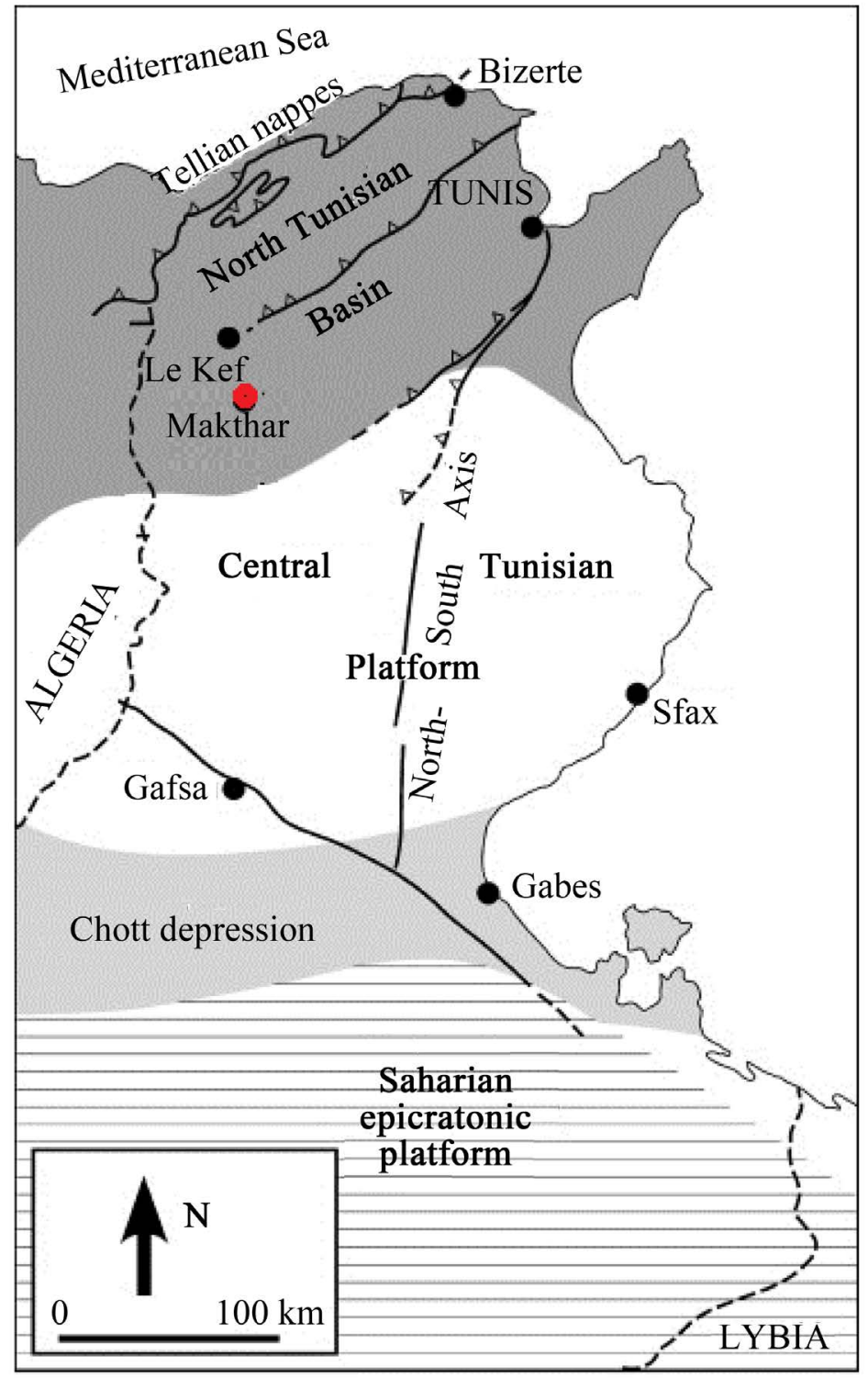

Figure 1. Location of the study area. 
The realized studies were carried out on three clay formations, the most representative, taken from clay that outcrops $25 \mathrm{Km}$ from Makthar city to evaluate their potential use in the ceramic field.

\section{Materials and Methods}

\subsection{Mineralogical Study by X-Ray Diffraction}

Mineralogical analysis was carried out with a Philips Xpert Pro MD standard beam with copper anti-cathode tube. The mineralogical characterization identifies the percentages of clay minerals $(<2 \mu \mathrm{m})$ and associated minerals [6] [7].

\section{Chemical Analysis}

The chemical analysis of major elements was carried out by atomic absorption Perkin Elmer apparatus with acetylene peroxide flame. This analysis allows us to determine the percentages of $\mathrm{CaO}, \mathrm{Fe}_{2} \mathrm{O}_{3}, \mathrm{Al}_{2} \mathrm{O}_{3}, \mathrm{SiO}_{2}, \mathrm{~K}_{2} \mathrm{O}$, $\mathrm{MgO}, \mathrm{Na}_{2} \mathrm{O}, \mathrm{SO}_{4}$, and loss on ignition.

\subsection{Granulometric and Micro-Granulometric Analysis}

This analysis was carried out under water and the refusal of each sieve was dried and weighed [8]. The micro-size analysis was performed with the Mikromeritics SediGraph 5120 particle size analyzer, size range 0.1 $300 \mu \mathrm{m}$ [9]. The particle diameter was determined by measuring the speed of sedimentation of suspended particles according to Stokes law [10].

\subsection{Plasticity}

Plasticity was determined by the Atterberg limits. Those physical constants define the threshold for passing from a liquid state to a plastic state expressed in water content. Limit liquidity and plastic limit were measured according to the [11]. The plasticity index represents the broad field of plasticity clays [12]. The evaluation of plasticity was performed by Atterberg limits method. The plasticity index was calculated as the arithmetic difference of liquid limit and plastic limit. This analysis was carried out with a Casagrande apparatus.

\subsection{Specific Surface Area}

Specific surface area by the methylene blue method was determined according to the standard EN ISO 10545-4 [13]. Specific surface area is directly related to the rate of phyllosilicates [14]. The adsorption test is used to classify clays [15] [16].

\subsection{Technological Tests}

Drying curve (Bigot) was determined using a D124 barellatographe apparatus while dilatometer curve is carried out using a dilatometer Adamel Lhomargy type BI. The registration was completed when the drying recording of clay is not accompanied by shrinkage. Drying and dilatometric curves allow highlighting the variations in weight and volume as a function of temperature [17].

For the manufacture of bricks, different bricks underwent a drying operation performed in the open air and then in an oven at $100^{\circ} \mathrm{C}$ and firing was done by means of an electric furnace at various levels of temperature $800^{\circ} \mathrm{C}, 850^{\circ} \mathrm{C}, 900^{\circ} \mathrm{C}$ and $950^{\circ} \mathrm{C}$. The rise of temperature increased from $30^{\circ} \mathrm{C} / \mathrm{h}$. For the manufacture of tiles, different tiles underwent a heating operation in an electric furnace at different temperatures $850^{\circ} \mathrm{C}, 900^{\circ} \mathrm{C}$, $950^{\circ} \mathrm{C}$ and $1000^{\circ} \mathrm{C}$ with a gradient of $300^{\circ} \mathrm{C} / \mathrm{h}$. The determination of water absorption and flexural strength were carried out following the Standards [18] [19].

\section{Experimental Results}

\subsection{Mineralogical Analysis}

The results of mineralogical analysis (Figure 2) showed a clear change in the bottom to the top of the outcrops which distinguishes three mineralogical units (Table 1).

The unit A Mkt consisted mainly by illite and low smectite and Kaolonite. The H Mkt was marked by the 


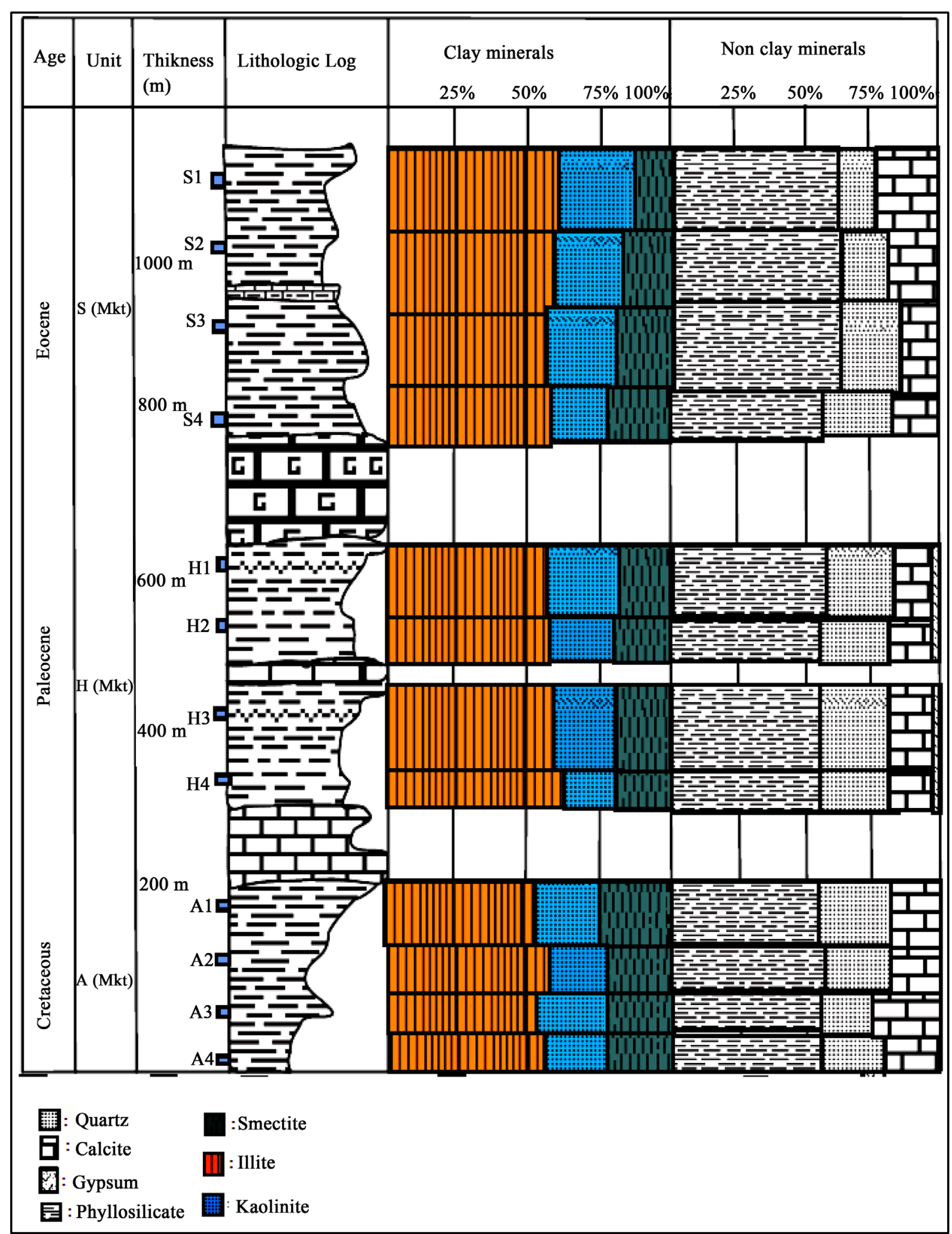

Figure 2. Mineralogical distribution of Makthar's clay.

increase in the content of illite and the percentage of smectite. The unit S Mkt was marked by the presence of illite and the kaolinite. Associated minerals were present at levels nearly homogeneous throughout the outcrops 
Table 1. Mineralogical composition of total samples.

\begin{tabular}{cccccccccc}
\hline & & \multicolumn{3}{c}{ Total (bulk) sample } & \multicolumn{3}{c}{$<2 \mu$ Fraction } \\
\hline Unit & Samples & Phyllosilicate & Quartz & Calcite & Gypsum & Illite & Kaolinite & Smectite \\
\hline Unit 3 & S1 Mkt & 62 & 15 & 23 & - & 62 & 25 & 13 \\
& S2 Mkt & 64 & 13 & 23 & - & 60 & 22 & 18 \\
& S3 Mkt & 64 & 17 & 19 & - & 58 & 25 & 17 \\
& S4 Mkt & 61 & 20 & 19 & - & 61 & 21 & 18 \\
& Hnit 2 & H1 Mkt & 60 & 16 & 23 & 1 & 55 & 30 & 15 \\
& H2 Mkt & 61 & 15 & 22 & 2 & 52 & 32 & 16 \\
& H3 Mkt & 62 & 11 & 25 & 2 & 50 & 31 & 19 \\
& H4 Mkt & 62 & 11 & 25 & 2 & 54 & 30 & 16 \\
& A1 Mkt & 55 & 25 & 20 & - & 65 & 20 & 15 \\
& A2 Mkt & 59 & 22 & 19 & - & 64 & 19 & 17 \\
& A3 Mkt & 58 & 17 & 25 & - & 62 & 19 & 19 \\
& A4 Mkt & 58 & 20 & 22 & - & 65 & 19 & 16 \\
\hline
\end{tabular}

and were mainly represented by calcite and a percentage of quartz. Mineralogical results showed the dominance of illite presenting favorable proprieties for ceramic use. The content of quartz was very tolerable since it can be easily digested by vitreous flow during firing operation [20].

\subsection{Chemical Analysis}

Chemical analysis of the major elements was performed on a mixture of clays (Table 2). The results showed high content of $\mathrm{CaO}$ and $\mathrm{Fe}_{2} \mathrm{O}_{3}$. The percentage of $\mathrm{SiO}_{2}$ indicated the importance of detrital contribution. $\mathrm{Al}_{2} \mathrm{O}_{3}$ had a relatively low percentage. Its origin cannot be the tetrahedral layer of clay minerals. The $\mathrm{K}_{2} \mathrm{O}$ content was very high; it's probably related to the presence of micas. Levels of alkaline fluxes $\left(\mathrm{Na}_{2} \mathrm{O}\right.$ and $\left.\mathrm{K}_{2} \mathrm{O}\right)$ present high level for all clay mixture due to the relatively larger amount of illite and orthoclase [21]. By comparing this clay with a fireclay, whose alumina rate was higher than $45 \%$, the alkaline fluxes lower than $4 \%$, it can be remarked that the clay of Makthar area was very plastic and was cooked red since the percentage of $\mathrm{Fe}_{2} \mathrm{O}_{3}$ is higher than $1.5 \%$. The problem of sulfur will be corrected by the addition of barium carbonate to the paste, which will form a more stable barium sulfate. The high loss on ignition (17\%) associated with low $\mathrm{SiO}_{2}$ and high $\mathrm{Al}_{2} \mathrm{O}_{3}$ contents were due to the significant content of clay minerals. Besides its fluxing role, $\mathrm{Fe}_{2} \mathrm{O}_{3}$ also provides the fired products the characteristic reddish colour. However, $\mathrm{Fe}_{2} \mathrm{O}_{3}$ is not the only factor responsible for the coloration of ceramic wares, as also other constituents such as $\mathrm{CaO}, \mathrm{MgO}, \mathrm{MnO}$ and $\mathrm{TiO}_{2}$ can appreciably modify the colour of fired clays [22]. The temperature of firing, the amount of $\mathrm{Al}_{2} \mathrm{O}_{3}$ relative to a range of other constituents, and the furnace atmosphere all play an important role in the development of colour in the fired clay products [23].

\subsection{Granulometric and Microgranulometric Analysis}

The particle size distribution of clay is a factor in determining its suitability for various applications, and particular attention should be given to the finer fraction $(<2 \mu \mathrm{m})$ for ceramic products [9]. Granulometric analysis of clay indicated a homogeneous distribution. These results showed that the clay samples had sand fraction about 15\% for unit A Mkt, 9\% for the H Mkt and 5\% for unit S Mkt. The percentage of elements whose diameter higher than $50 \mu \mathrm{m}$ was negligible and approximately reached $5 \%$ for all units (Figure 3).

The microgranulometric analysis of clay mixtures showed that the elements whose diameter was lower than 2 $\mu \mathrm{m}$ was very high and reached 30\%, for the unit $\mathrm{H} \mathrm{Mkt,} \mathrm{37 \%} \mathrm{for} \mathrm{the} \mathrm{unit} \mathrm{A} \mathrm{Mkt} \mathrm{and} \mathrm{35 \%} \mathrm{for} \mathrm{the} \mathrm{unit} \mathrm{S} \mathrm{Mkt.}$ The granulometry of all studied clays was excellent for use in ceramics. The problem arising by the presence of particles in the coarse sand fraction $(200-2000 \mu \mathrm{m})$ can be solved simply by grinding.

The micro-size curves (Figure 4) for clay units H Mkt and A Mkt showed a parabolic facies indicating a 
Table 2. Clay’s chemical analysis.

\begin{tabular}{|c|c|c|c|c|c|c|c|c|c|}
\hline Clay & & L.O.I \% & $\mathrm{CaO} \%$ & $\mathrm{Al}_{2} \mathrm{O}_{3} \%$ & $\mathrm{Fe}_{2} \mathrm{O}_{3} \%$ & $\mathrm{SiO}_{2} \%$ & MgO \% & $\mathrm{SO}_{3} \%$ & $\mathrm{~K}_{2} \mathrm{O} \%$ \\
\hline \multirow{4}{*}{ A Mkt } & A1 & 17.64 & 7.49 & 17.48 & 7.88 & 36.47 & 3.63 & 0.08 & 1.11 \\
\hline & A2 & 13.95 & 8.54 & 8.61 & 7.52 & 37.94 & 2.76 & 1.8 & 0.88 \\
\hline & A3 & 23.48 & 2.73 & 12.25 & 9.22 & 43.58 & 2.89 & 0.02 & 1.88 \\
\hline & A4 & 14.36 & 8.76 & 8.64 & 7.47 & 37.6 & 2.70 & 1.83 & 0.87 \\
\hline \multirow[t]{4}{*}{ H Mkt } & H1 & 22.41 & 26.64 & 7.5 & 5.86 & 31.35 & 0.5 & 3 & 0.47 \\
\hline & H2 & 31.29 & 24.21 & 16.55 & 3.87 & 20.29 & 0.2 & 0.8 & 0.55 \\
\hline & H3 & 12.90 & 20.0 & 15.91 & 2.63 & 47.59 & 0.86 & 0.13 & 0.53 \\
\hline & $\mathrm{H} 4$ & 20.86 & 26.29 & 9.33 & 6.08 & 38.99 & 1.95 & 2.99 & 0.51 \\
\hline \multirow[t]{4}{*}{ S Mkt } & $\mathrm{S} 1$ & 23.48 & 26.0 & 14.79 & 2.52 & 23.42 & 1.46 & 0.09 & 0.93 \\
\hline & $\mathrm{S} 2$ & 22.54 & 25.17 & 14.85 & 2.54 & 22.89 & 1.35 & 0.09 & 0.92 \\
\hline & S3 & 24.84 & 28.36 & 18.82 & 3.64 & 37.3 & 1.52 & 1.72 & 0.58 \\
\hline & $\mathrm{S} 4$ & 21.34 & 27.11 & 18.69 & 3.71 & 32.01 & 1.62 & 1.88 & 0.54 \\
\hline
\end{tabular}

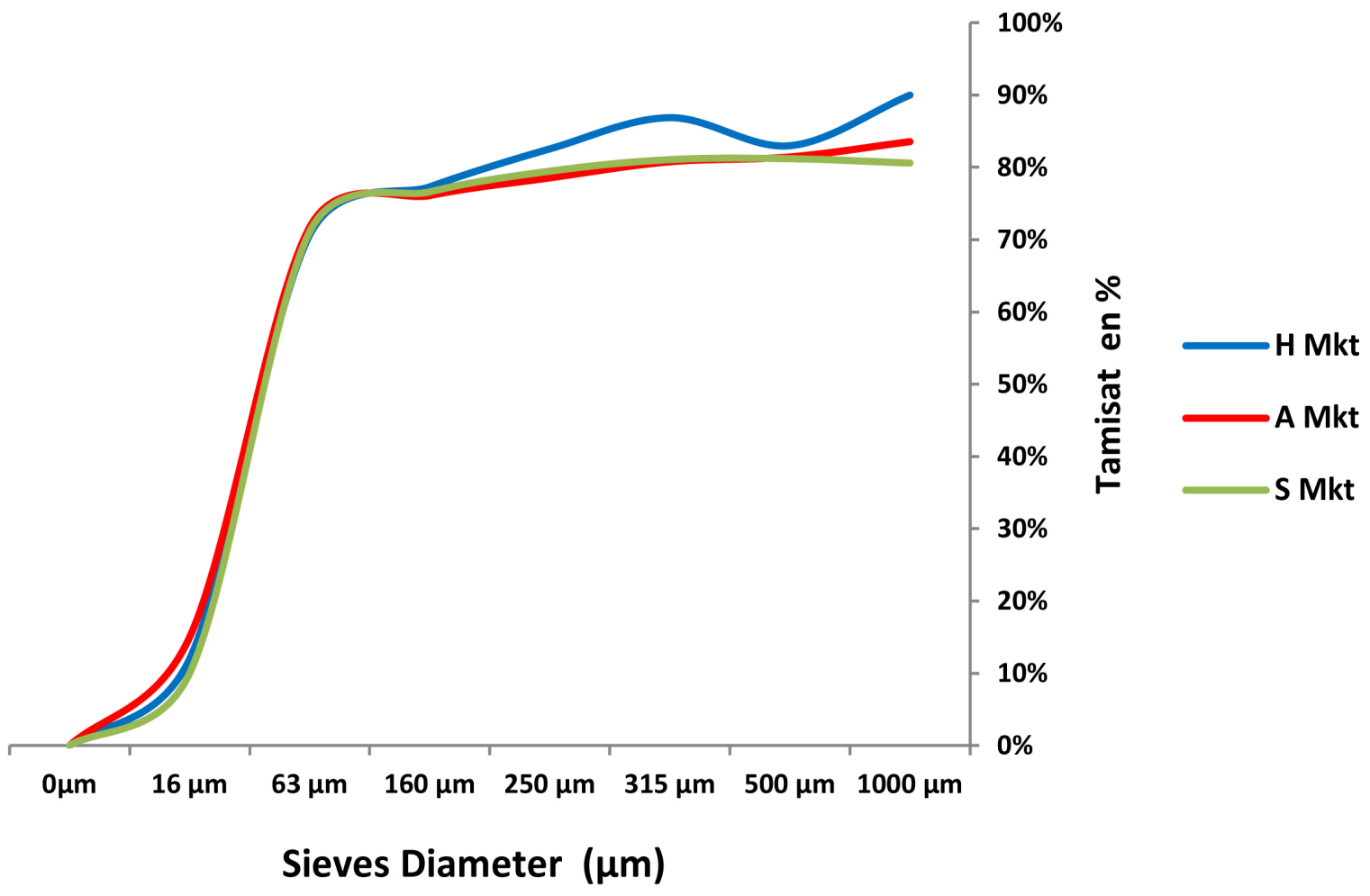

Figure 3. Granulometric curves of different mixture clay of Makthar area.

transport operation either by turbidity currents at medium speed or by suspension graduated suspension [24].

\subsection{Plasticity Tests}

The values of the limits of plasticity and plasticity index values indicated that all mixture clay of Makthar area plastic-type (Table 3). These clay mixtures were located in the area of illitic minerals as shown on Holtz and Kovacs diagram (Figure 5). This is of importance for applications since it indicated the minimum moisture content necessary to reach a plastic condition. At a high plastic limit, the samples were more difficult to dry. On 

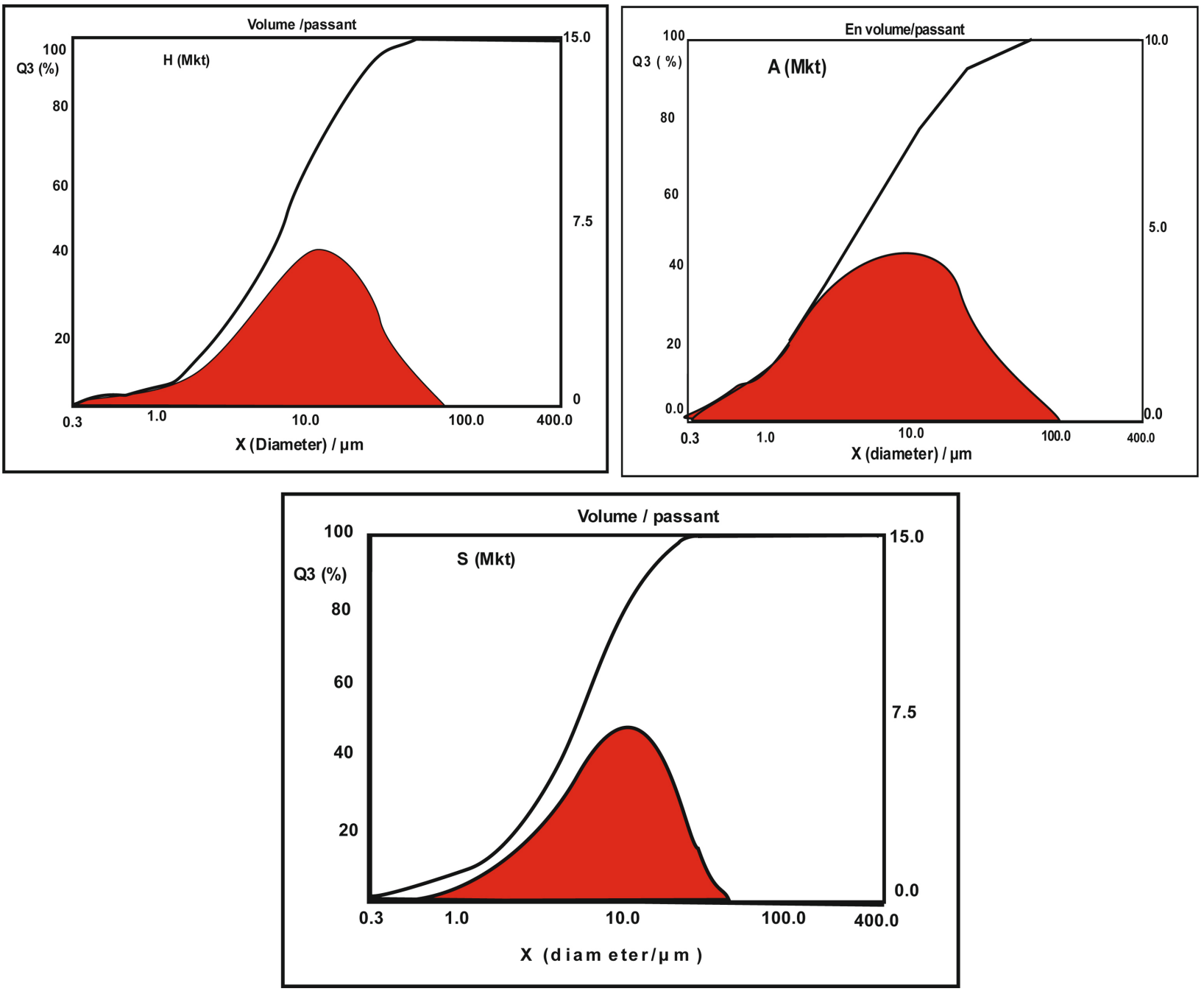

Figure 4. Micro-granulometric curves of different mixture clay of Makthar area.

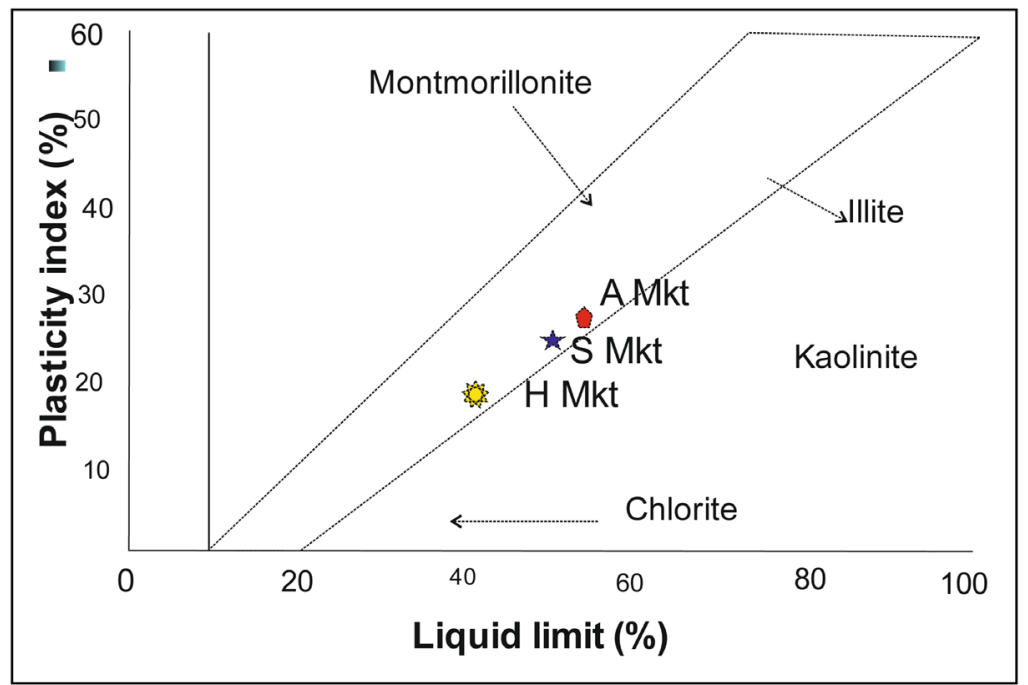

Figure 5. Position of the studied clays on the Holtz and Kovacs diagram. 
Table 3. Plasticity of mixture clay of Makthar area.

\begin{tabular}{cccccc}
\hline Units & References & WL & Wp & Ip & Plasticity field \\
\hline U1 & A Mkt & 54.34 & 36.05 & 26.28 & \\
U2 & H Mkt & 42.75 & 26.35 & 18.39 & Plastic clay \\
U3 & S Mkt & 57.83 & 32.77 & 25.05 & \\
\hline
\end{tabular}

the other hand, the use of high plastic clays reduced the wearing down of the equipment for grinding and conformation (extruder). High plasticity was associated with bodies with greater mechanical strength [21]. Figure 5 shows the position of these clays on the Holtz and Kovacs diagram [25]. The almost same PI value for all clays may be related to higher plastic limit of illite (35\% - 60\%) and montmorillonit (50\% - 100\%) than kaolinite $(25 \%-40 \%)$ [26].

\subsection{Specific Surface Area}

The mixture of clays of all clay units had specific surface which reflect illitic character (Table 4). We noted that the value of the specific surface was strongly influenced by the nature of the clay minerals and associated minerals. However, the presence of high levels of calcium carbonate can significantly diminish the value of the specific surface.

\subsection{Drying and Cooking Behavior}

\subsubsection{Bigot Curve}

The results of drying curves for the mixtures studied are shown in Figure 6. For each unit, the drying behavior is performed on mixtures formed by clay samples. The clay mixture A Mkt unit had a percentage of total water of $25.14 \%$. The percentage of interposed water was $5.14 \%$, while the percentage of colloidal water was $20 \%$. The final drying shrinkage was $5.7 \%$. The clay mixture of the $\mathrm{H}$ Mkt showed a percentage of total water of $28.44 \%$. The percentage of interposed water was $8.44 \%$ and the percentage of colloidal water was $20 \%$. The final drying shrinkage was $6.8 \%$. The clay mixture of S Mkt unit had a percentage of total water of $31 \%$. The percentage of interposed water was $10.4 \%$ while the percentage of colloidal water was $20.6 \%$. The final drying shrinkage was $7.2 \%$. The different results obtained indicated that different clays were preparing quick-drying.

\subsubsection{Dilatometric Curves}

The dimensional changes observed after firing of the raw clays are given in Figure 7. For the unit A Mkt showed that from ambient temperature to $110^{\circ} \mathrm{C}$, developed a slight dilation which didn't not exceed $0.2 \%$, this was due to desorption of adsorbed water. This expansion was followed by larger changes between 500 and $600^{\circ} \mathrm{C}$ due to the $\alpha \rightarrow \beta$-quartz transformation. This dilation reached $2.2 \%$ at temperature $750^{\circ} \mathrm{C}$ (segment $\mathrm{AB}$ ). Singer and Singer (1963) point out that $\alpha$-quartz transformed into $\beta$-quartz at $573^{\circ} \mathrm{C}$ with a volume increase of $2 \%$ and on further slow heating $\beta$-quartz changed to $\beta 2$-tridymite at $870^{\circ} \mathrm{C}$ with a volume increase of $12 \%$. The maximum expansion rate between $500^{\circ} \mathrm{C}$ and $600^{\circ} \mathrm{C}$ was $583^{\circ} \mathrm{C}$. After a slight shrinkage starting at around $850^{\circ} \mathrm{C}$, a sharp shrinkage starting at $952^{\circ} \mathrm{C}$ was attributed to sintering and the formation of vitreous phases (segment BC). This mean interval of temperature gave the opportunity to the grains to react correctly between them and give materials that will resist to the deformation at high temperature, favorable asset for the ceramic production. This phenomenon deviated greater from $800^{\circ} \mathrm{C}$ to $1000^{\circ} \mathrm{C}$ indicating the end of fusible phase of the product (segment $\mathrm{CD}$ ). The segment (DE) corresponded to the cooling. This curve was almost linear, indicating a cooking withdrawal of $1.6 \%$. Dilatometric curve of the unit $\mathrm{H}$ Mkt showed that from ambient temperature to $120^{\circ} \mathrm{C}$, developed a slight dilation of $0.2 \%$ followed by maximum dilation of $2.2 \%$ at $750^{\circ} \mathrm{C}$ (segment $\mathrm{AB}$ ). From $750^{\circ} \mathrm{C}$, there was the beginning of sintering phase (segment BC). This phenomenon deviated greater from $800^{\circ} \mathrm{C}$ to $900^{\circ} \mathrm{C}$ indicating the end of this phase (segment CD). The segment (DE) corresponded to the cooling phase indicating a final firing shrinkage of $2 \%$. Dilatometric curve of the unit S Mkt showed that from ambient temperature to $120^{\circ} \mathrm{C}$, developed a shrinkage of $0.5 \%$ followed by a maximum dilation of $2.3 \%$ at $800^{\circ} \mathrm{C}$ (segment $\mathrm{AB}$ ). From $800^{\circ} \mathrm{C}$, there was a gradual contraction and the beginning of the fusible phase (segment $\mathrm{BC}$ ). This phenomenon deviated from $800^{\circ} \mathrm{C}$ to $870^{\circ} \mathrm{C}$ indicating the end of fusible phase (segment $\mathrm{CD}$ ). The 
Table 4. Specific surface area analysis.

\begin{tabular}{cccccccccccccc}
\hline Unit & \multicolumn{4}{c}{ Unit 1 } & \multicolumn{1}{c}{ Unit 2 } & \multicolumn{4}{c}{ Unit 3 } \\
\hline Samples (Mkt) & A1 & A2 & A3 & A4 & H1 & H2 & H3 & H4 & S1 & S2 & S3 & S4 \\
SSA (m $\left.\mathbf{m}^{2} / \mathbf{g}\right)$ & 112 & 178 & 176 & 180 & 210 & 220 & 235 & 255 & 250 & 265 & 270 & 230 \\
\hline
\end{tabular}

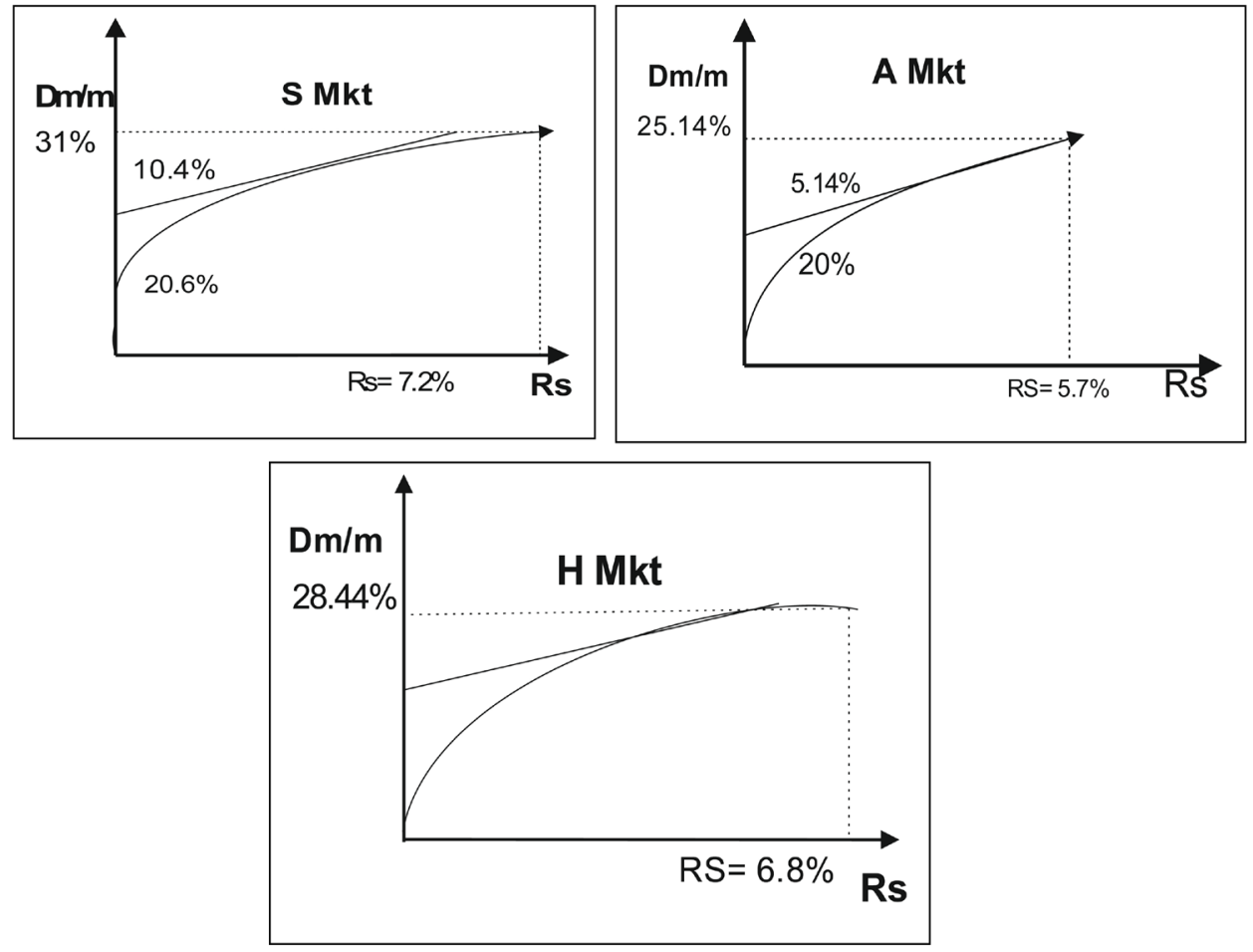

Figure 6. Drying curves of clay mixture of Makthar area: A Mkt, H Mkt and S Mkt.

segment (DE) corresponded to the cooling phase indicating a final firing shrinkage of $1.25 \%$. The higher content of $\mathrm{K}_{2} \mathrm{O}$ in all raw material, especially in $<2 \mu \mathrm{m}$ fraction, may contribute to the rapid vitrification.

\subsubsection{Technological Tests for Bricks}

Test results for manufacturing bricks are shown in Table 5. Drying shrinkage of the mixture clay of the unit A Mkt was almost of 5.7\%, while for the two mixtures of $\mathrm{H}$ Mkt and S Mkt units, it was almost of 7\%. Firing shrinkage of the product presented satisfactory values which depended on the temperature, and reached $2.27 \%$ for A Mkt, a value of $1.86 \%$ for the mixture $\mathrm{H} \mathrm{Mkt}$ and a value of $1.37 \%$ for S Mkt at $950^{\circ} \mathrm{C}$.

Loss of ignition increases slightly with the temperature and varies according to the presence of carbonates in the clays. It reached maximum values at $950^{\circ} \mathrm{C}$. The percentage of loss on ignition was closely related to the molecular water, the oxidation of $\mathrm{FeO}$, the decomposition of carbonates and the presence of organic matter. The water absorption varied inversely when the temperature increase, it decreased sharply to $10.11 \%$ for A Mkt, to $15.15 \%$ for $\mathrm{H} \mathrm{Mkt}$, and $12 \%$ for S Mkt to $950^{\circ} \mathrm{C}$. All raw material mixture had almost color tending to red and yellow Figure 8. The increased redness and yellowness can be attributed to more amount of some oxide impurities. The different values and the red color appearance of the product were very tolerable which makes different material very profitable for industrial exploitation [27].

\subsubsection{Technological Tests of Ceramic Tiles}

For each temperature, we proceeded to heat five pieces of clay mixtures. The results are shown in Table 6 . The flexural strength reaches $11 \mathrm{MPa}$ to $12 \mathrm{MPa}$ for all clay units at $1000^{\circ} \mathrm{C}$. The mechanical resistance to the flexion increased with vitrification up to high level of resistance, then the material becomes breakable. For all clay 
I. Ben Salah et al.

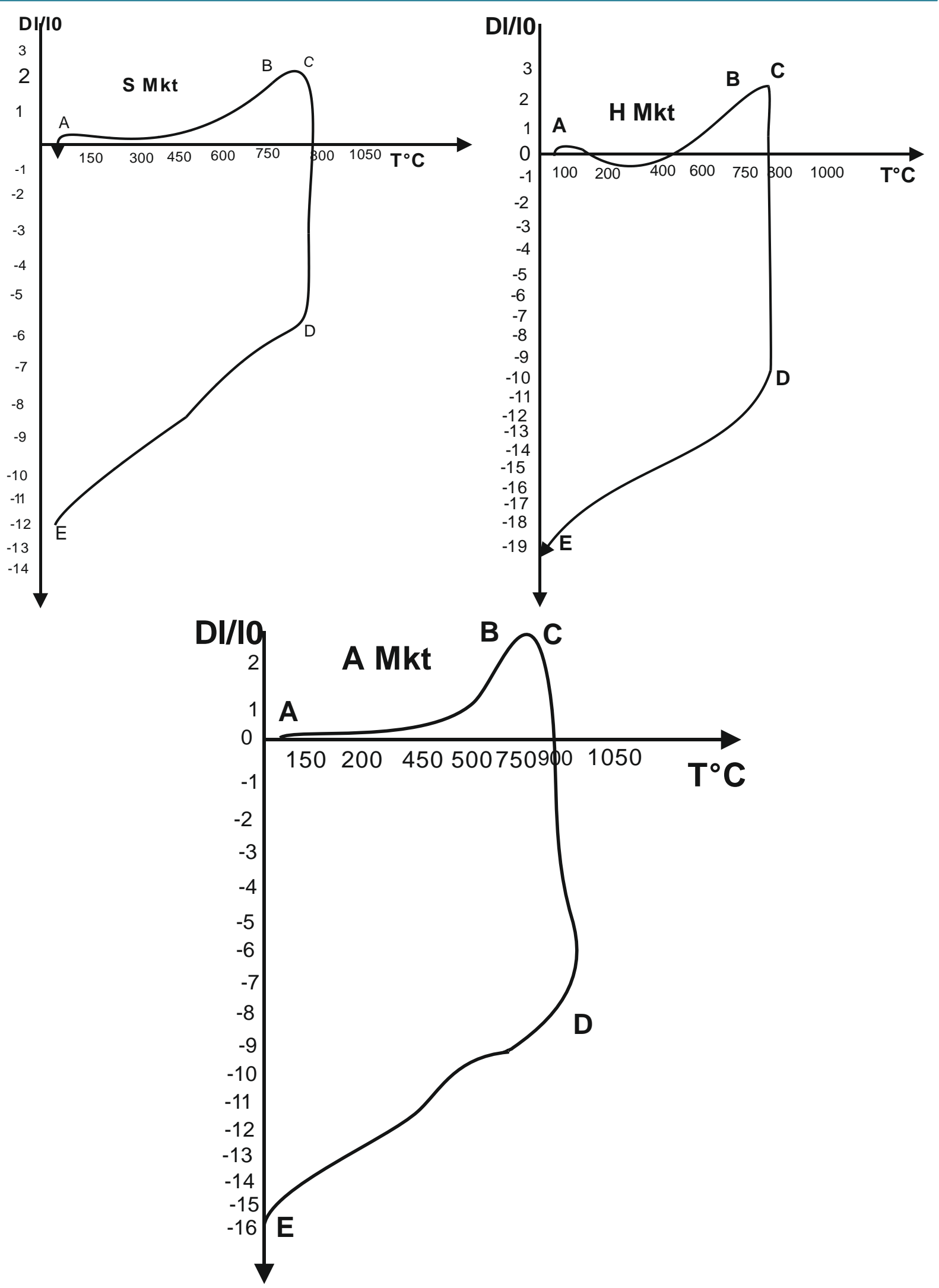

Figure 7. Dilatometric curves of clay mixture: A Mkt, H Mkt and S Mkt.

(635) 


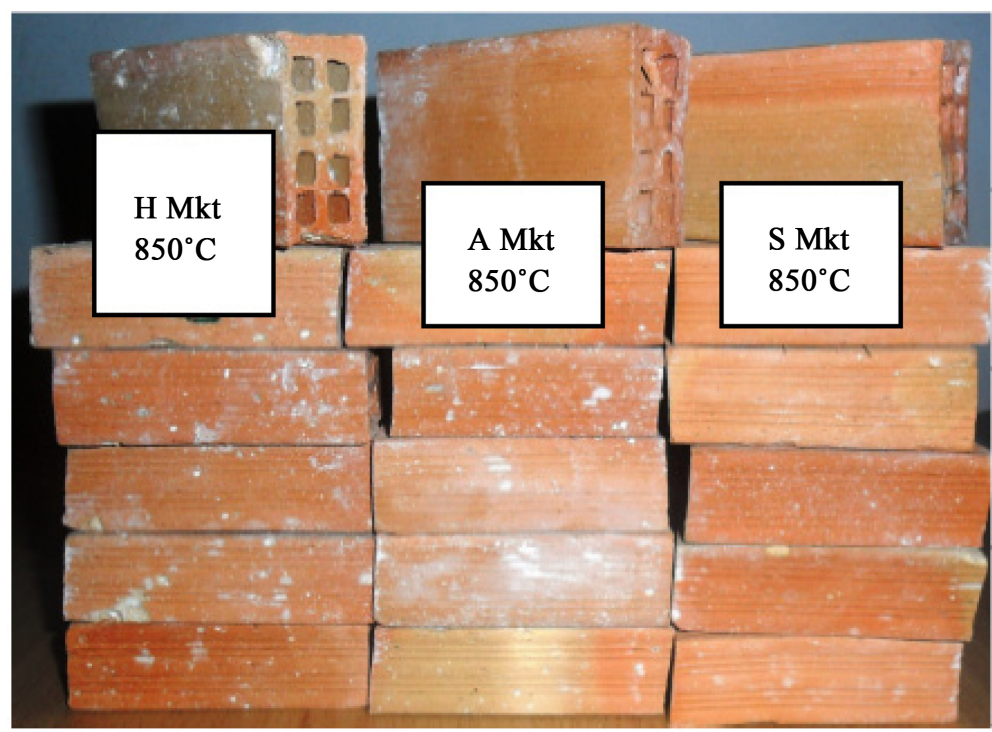

Figure 8. Different types of bricks from the clay of different section.

Table 5. Results of technological test of bricks.

\begin{tabular}{|c|c|c|c|c|c|}
\hline Unit & Temperature $^{\circ} \mathbf{C}$ & $\begin{array}{c}\text { Drying Shrinkage } \\
\text { (\%) }\end{array}$ & $\begin{array}{c}\text { Firing Shrinkage } \\
(\%)\end{array}$ & $\begin{array}{c}\text { Loss of Ignition } \\
(\%)\end{array}$ & $\begin{array}{c}\text { Water Absorption } \\
(\%)\end{array}$ \\
\hline \multirow{4}{*}{ U1 (A Mkt) } & 800 & \multirow{4}{*}{$5.7 \%$} & 0.22 & 6.8 & 15 \\
\hline & 850 & & 0.40 & 6.9 & 13.9 \\
\hline & 900 & & 1.27 & 7 & 13.02 \\
\hline & 950 & & 2.27 & 7.53 & 10.11 \\
\hline \multirow{4}{*}{ U2 (H Mkt) } & 800 & \multirow{4}{*}{$7 \%$} & 0.03 & 17 & 15.9 \\
\hline & 850 & & 0.25 & 17.32 & 15.6 \\
\hline & 900 & & 1.43 & 18.12 & 15.5 \\
\hline & 950 & & 1.86 & 19.4 & 15.15 \\
\hline \multirow{4}{*}{ U3 (SMkt) } & Lo & \multirow{4}{*}{$7.5 \%$} & 0.06 & 17.4 & 16.17 \\
\hline & 20.0 & & 0.19 & 17.3 & 14.46 \\
\hline & 20.0 & & 1.13 & 17.8 & 12.12 \\
\hline & 20.0 & & 1.37 & 17.85 & 12.00 \\
\hline
\end{tabular}

mixture, the temperature of $1000^{\circ} \mathrm{C}$ represented the limit of the mechanical resistance to the flexion. The firing temperature had an important effect on the mechanical strength of ceramic tile. The temperature increased the flexural strength due to densification. As the liquid phase reduced the porosity, which hinders crack formation and improved the mechanical strength. Higher proportions of orthoclase in the fraction $<2 \mu \mathrm{m}$ of raw material favored vitrification and improved resistance of fired samples.

Above $900^{\circ} \mathrm{C}$, the values of water absorption decreased and the amount of the liquid phase increased. This phase penetrated into the pores, closing them and isolating neighbouring pores. The liquid surface tension and capillarity helped to bring pores closer together and reduced porosity. This explains the intense decrease of the water absorption in this temperature range [28]. The firing shrinkage up to $1000^{\circ} \mathrm{C}$ was small around $1 \%$ for all raw materials.

Based on these results, these clays can be used in the field of manufacturing of bricks, without being broken or damaged by local constraints. However, technological tests of ceramic tiles showed that units A Mkt and S Mkt prepare well to get ceramic tile type $\mathrm{B}_{\mathrm{III}}$ [29] (Figure 9). In contrast, the mixture of the $\mathrm{H}$ Mkt has some 
Table 6. Results of technological test of tiles.

\begin{tabular}{|c|c|c|c|c|c|c|}
\hline Unit & Temperature ${ }^{\circ} \mathrm{C}$ & $\begin{array}{c}\text { Drying } \\
\text { Shrinkage (\%) }\end{array}$ & $\begin{array}{c}\text { Firing } \\
\text { Shrinkage (\%) }\end{array}$ & $\begin{array}{c}\text { Loss of } \\
\text { Ignition (\%) }\end{array}$ & $\begin{array}{c}\text { Bending strength } \\
\mathrm{N} / \mathrm{mm}^{2}\end{array}$ & $\begin{array}{c}\text { Water } \\
\text { Absorption \% }\end{array}$ \\
\hline \multirow{4}{*}{ U1 (A Mkt) } & 850 & \multirow{4}{*}{$0.11 \%$} & 0.3 & 7.2 & 2.3 & 10.73 \\
\hline & 900 & & 0.66 & 7.24 & 5.52 & 15.64 \\
\hline & 950 & & 0.90 & 7.13 & 10.21 & 16.98 \\
\hline & 1000 & & 0.90 & 7.6 & 10.52 & 18.73 \\
\hline \multirow{4}{*}{ U2 (H Mkt) } & 850 & \multirow{4}{*}{$0.28 \%$} & 0.5 & 17.2 & 3.3 & 26.18 \\
\hline & 900 & & 0.18 & 18.0 & 4.08 & 28.01 \\
\hline & 950 & & 0.08 & 19.8 & 4.8 & 30.4 \\
\hline & 1000 & & 0.02 & 20.0 & 5.25 & 31.7 \\
\hline \multirow{4}{*}{ U3 (SMkt) } & 850 & \multirow{4}{*}{$0.25 \%$} & 0.70 & 17.61 & 5.4 & 16.55 \\
\hline & 900 & & 0.85 & 17.99 & 9.42 & 18.88 \\
\hline & 950 & & 1.98 & 18.4 & 10.01 & 20.9 \\
\hline & 1000 & & 1.22 & 18.51 & 12.68 & 21.19 \\
\hline
\end{tabular}

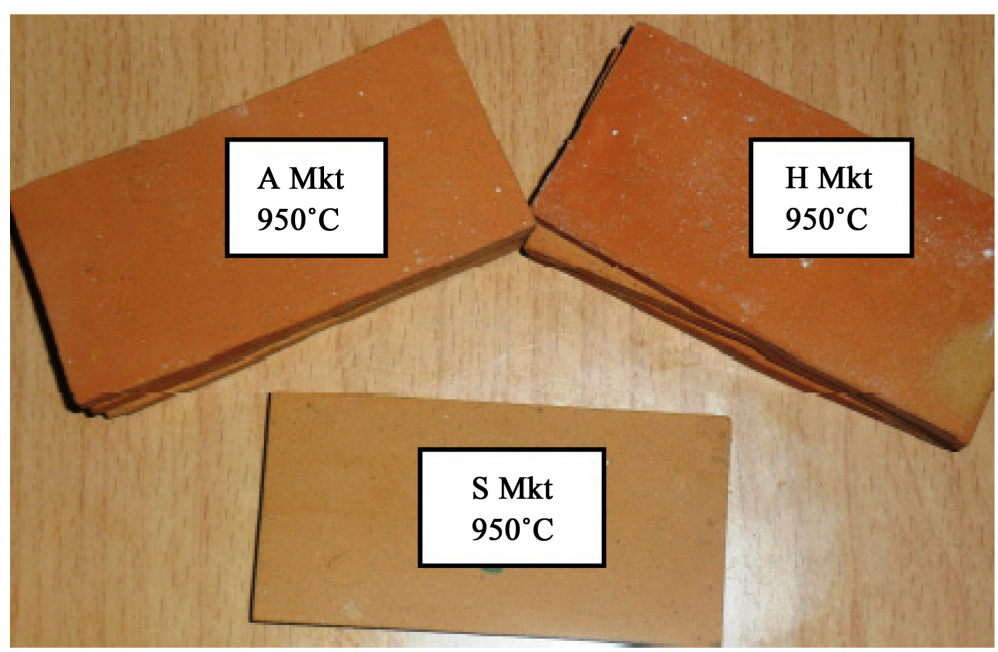

Figure 9. Different types of tiles from different clay sections.

defects which amount to a lifting surface (swelling). This defect may remedied by increasing the rate of greaser remover [30].

\section{Conclusions}

Mineralogical analysis of clay mixture of Makthar area showed dominance of Illite with a small percentage of kaolinite and smectite. These clay minerals combined high content of calcite and quartz. This analysis showed relatively low values of the specific surface area and high values of plasticity index which confirmed the plastic character of clays according to the Casagrande diagram.

The geochemical analysis showed that the argillaceous series had a ratio of $\mathrm{SiO}_{2} / \mathrm{Al}_{2} \mathrm{O}_{3}$ nearly 2. The $\mathrm{K}_{2} \mathrm{O}$ content was almost $4 \%$ and the content of $\mathrm{Fe}_{2} \mathrm{O}_{3}$ was relatively large. The high percentage of $\mathrm{CaO}$ showed the enrichment of clay calcite and was confirmed by the high content of loss on ignition.

Technological Tests for bricks revealed a firing temperature of $900^{\circ} \mathrm{C}$, a drying shrinkage of $7 \%$, a weight loss of $20 \%$ and water absorption of $9 \%$. However, technological tests for ceramic tiles, showed values of firing temperature of $1050^{\circ} \mathrm{C}$, firing shrinkage of $0.25 \%$, a flexural strength of $11 \mathrm{MPa}$ and water absorption of $2 \%$. The red color appearance obtained at the end of firing operation is favorable for use in ceramic industry despite 
the presence of some defects which are easily remediable by chemical corrections.

\section{Acknowledgements}

Sincere thanks go to the staff of the Ceramic Laboratory of the technical center of construction materials, ceramic and glass (CTMCCV, Tunisia).

\section{References}

[1] Ben Ayed, N. (1975) Etude géologique de cuvettes de Siliana et du Sers (Atlas Tunisien central). Thèse 3ème cycle, Universite Pierre et Marie Curie, Paris, 82.

[2] M'Rabet, A. (1987) Stratigraphie, Sédimentation et diagénèse carbonatée des séries Crétacé inférieur de la Tunisie Centrale. Thèse 3ème cycle, 412.

[3] Burollet, P.F. (1973) Importance deds facteurs salifères dans la tectonique tunisienne. Annales de Minéralogie et de Géologie, 26, 110-120.

[4] Castany, G. (1952) Paléogéographie, tectonique et orogenèse de la Tunisie. XIXème Congrès géologique international, Alger.

[5] Turki, M.M. (1988) Polycinématique et contrôle sédimentaire associé sur la cicatrice Zaghouane-Nebhana. Mémoire, 7, 252.

[6] Srasra, E. (1987) Caractérisation minéralogique, propriétés physico-chimiques et application de l'argile de Haidoudi. Thèse de doctorat 3ème cycle, Faculté des Sciences de Tunis.

[7] Amri, M. (1988) Inventaire des argiles smectitique et leurs éventuelles utilisations dans l'industrie: Les smectites du Paléocène-Eocène inférieur dans les bassins du Centre-Ouest et du Sud-Ouest de la Tunisie. Thèse 3ème cycle, Faculté des Sciences, Tunis, 148.

[8] Norme XP P 94-041 (1995) Identification granulométrique. Méthode de tamisage par voie humide.

[9] Mahmoudi, S., Srasra, E. and Zargouni, F. (2008) The Use of Tunisian Barremian Clay in the Traditional Ceramic Industry: Optimization of Ceramic Properties. Applied Clay Science, 42, 125-129. http://dx.doi.org/10.1016/j.clay.2007.12.008

[10] Nahdi, K. (1997) Identification physico-chimique de l'argile de jebel Ressas. Application aux céramiques. Mémoire de D.E.A., Tunis, 86 .

[11] Norme NFP 94-051 (1993) Reconnaissance et essais. Détermination des limites d'Atterberg. Limite de liquidité à la coupelle. Limite de plasticité au rouleau.

[12] GTR-LCPC (1987) Limites d'Atterberg, limite de liquidité, limite de plasticité, Méthodes d'essai. LCPC, 26.

[13] Norme EN ISO 10545-4 (2012) Mesure de la quantité d'adsorption de bleu de Méthylène d’un sol ou d'un matériau rocheux par l'essai de tâche.

[14] Jamoussi, F. (2001) Les argiles de la Tunisie: Etude minéralogique, géochimique, géotechnique et utilisations industrielles. Thèse d'État, université El Manar, Tunis.

[15] GTR-LCPC (1992) Guide Technique pour la réalisation des remblais et des couches de forme.

[16] GTR-LCPC (2000) Guide Technique pour le traitement du sol à la chaux et/ou aux liants hydrauliques.

[17] Hachani, M. (2004) Caractérisation et valorisation des argiles du Crétacé inférieur du Jebel Zitoun (région de Krib) Tunisie Nord orientale. Mémoire Mastère en géologie appliquée, Université de Carthage, Tunis.

[18] Norme ISO 10545-4 (2004) Carreaux et dalles céramiques-Partie 4: Détermination de la résistance à la flexion et de la force de rupture.

[19] Norme ISO 10545-3 (2004) Carreaux et dalles céramiques—Partie 3: Carreaux et dalles céramiques—Détermination de l'absorption d'eau.

[20] Ben Salah, I. (2003) Etude des matériaux utiles du Crétacé supérieur et du Paléogène de la Tunisie centrale (région de Makthar). Mémoire de Mastère, Faculté des Sciences de Tunis, 85, Tunis.

[21] Monterio, S.N. and Vieira, C.M.F. (2004) Influence of Firing Temperature on the Ceramic Properties of Clays from Campos dos Goytacazes, Brazil. Applied Clay Science, 27, 229-234. http://dx.doi.org/10.1016/j.clay.2004.03.002

[22] Kreimeyer, R. (1987) Some Notes on the Firing Color of Clay Bricks. Applied Clay Science, 2, 175-183. http://dx.doi.org/10.1016/0169-1317(87)90007-X

[23] Fisher, P. (1984) Some Comments on the Color of Fired Clays. Ziegel Industrie International, 37, 475-483.

[24] Ben M’Barek, M. (1996) Identification et valorisation des argiles du Paléogène du Nord de la Tunisie et leurs 
applications industrielles. DEA, Faculté des Science de Tunis, 91.

[25] Holtz, R.D. and Kovacs, W.D. (1981) Part 3: The Relationship between Geology and Landslide Hazards of Atchison, Kansas and Vicinity. Kansas Geotechnical Survey, Current Research in Earth Science, 244, 733-808.

[26] Mitchell, J.K. (1993) Fundamentals of Soil Behavior. 2nd Edition, John Wiley \& Sons, Hoboken.

[27] Cherni, R. (2008) Les argiles du Crétacé supérieur-Paléocène de la région Bir M’Chergua et de Jebel Kharouba. Biostratigraphie et apports industriels. Diplôme Etudes Approfondies, Faculté Des Sciences de Bizerte, 98.

[28] Baccour, H., Medhioub, M., Jamoussi, F. and Mhiri, T. (2009) Influence of Firing Temperature on the Ceramic Properties of Triassic Clays from Tunisia. Journal of Materials Processing Technology, 209, 2812-2817. http://dx.doi.org/10.1016/j.jmatprotec.2008.06.055

[29] Ben M’Barek, M. (2001) Les argiles du Crétacé et du Paléogène du Nord Est de la Tunisie: Caractérisation et essais d'applications industrielles.

[30] Handous, M.F. (1990) Etude céramique et essai industriel des argiles du Nord-Est de la Tunisie pour la fabrication de terre cuite. DEA, Faculté des Sciences de Tunis, 122.

\section{Submit or recommend next manuscript to SCIRP and we will provide best service for you:}

Accepting pre-submission inquiries through Email, Facebook, LinkedIn, Twitter, etc.

A wide selection of journals (inclusive of 9 subjects, more than 200 journals)

Providing 24-hour high-quality service

User-friendly online submission system

Fair and swift peer-review system

Efficient typesetting and proofreading procedure

Display of the result of downloads and visits, as well as the number of cited articles

Maximum dissemination of your research work

Submit your manuscript at: http://papersubmission.scirp.org/ 